\title{
Research on the Transformation from Financial Accounting to Management Accounting under the Background of Big Data
}

\author{
Yixi Zhang \\ Chongqing Real Estate Vocational College, Chongqing, 401331, China
}

Keywords: Big data; Financial accounting; Management accounting

\begin{abstract}
Accounting work is a very important content and component in the work of modern enterprises, which is conducive to the use and management of enterprise funds, so it is necessary to effectively carry out and implement accounting work. In the context of the current big data era, financial accounting no longer meets the development trends and needs of enterprises, and needs to be transformed into management accounting, so that the level and efficiency of enterprise accounting work can be effectively improved, and accounting work can be better carried out. On this basis to enable enterprises to achieve more ideal development and ensure that enterprises can obtain more ideal economic benefits. This paper expounds the research on the transformation of financial accounting to management accounting in the context of big data from different aspects, hoping to provide a theoretical reference for experts and scholars studying the transformation of financial accounting to management accounting.
\end{abstract}

\section{Introduction}

Financial accounting and management accounting are two very important forms in modern enterprise accounting work, and they play different roles in the development of accounting work, each with different advantages. In the context of the current big data era, traditional financial accounting methods can no longer meet the needs of actual accounting work, and need to be transformed into management accounting methods, so that the efficiency and level of accounting work can be effectively improved, and the development of accounting work can achieve more satisfactory results [1]. Enterprises can lay a better foundation and support for more ideal development, so accounting staff should actively implement the transformation from financial accounting to management accounting.

\section{The Difference between Financial Accounting and Management Accounting Functions}

Financial accounting is mainly based on accounting standards and generally refers to providing a comprehensive and systematic accounting and supervision of the capital movements that the enterprise has completed to provide external investors, creditors and relevant government departments with financial interests and financial aspects of the enterprise. Economic management activities such as profitability and other economic information as the main goal, financial accounting is an important basic work for modern enterprises. Through a series of accounting procedures to provide useful information for decision-making, and actively participate in business management decisions to improve the economy of the enterprise Benefits, serving the healthy and orderly development of the market economy, management accounting, also known as internal analysis report accounting, is a management term, mainly for the internally established department of the company, its main function is to strengthen the internal management of the enterprise, scientific management, Improve the economic interests of enterprises. Management accounting is separated from the traditional accounting system and is parallel to financial accounting. It is a branch of corporate accounting [2]. The main difference between the two is that management accounting analyzes and always prepares relevant economic data reports and submits them directly to the company's senior management personnel. Finance Accounting is always attached to accounting standards, and the company's financial situation needs to be summarized and reported 
objectively. In the first time, other departments can understand the company's financial situation at the first time. The effectiveness of management accounting hours is not limited to reflecting the company's past financial situation [3]. Accounting functions are mainly focused on accounting and supervising the financial status of enterprises, reflecting the actual economic data.

\section{Reasons for Transition from Financial Accounting to Management Accounting}

First, the country needs vigorous development. As the economy develops, accounting becomes more important. Therefore, the "Thirteenth Five-Year Plan" for Accounting Reform and Development proposes to use management accounting as the central task of accounting transformation and upgrading, and strive to cultivate a group of management accounting talents in the country within 3-5 years. Maintaining economic order is the mission and context of accounting management. The country strives to basically form a management accounting theory system with Chinese characteristics through 5-10 years of efforts, and establish a comprehensive management accounting guidance system to significantly strengthen the management accounting talent team. Management accounting the level of informatization has improved significantly, and the management accounting consulting service market has prospered significantly. In accounting management, both standard setting and personnel training are centered around the mission of maintaining economic order, and are closely centered on serving the overall situation of economic and financial work. Focusing on improving the quality of accounting information can effectively support economic and social development.

Second, the needs of enterprise development. From the perspective of the company's practical work, financial accounting can often only reflect the company's current capital operation. Financial accounting is often restricted by laws and regulations such as corporate accounting standards, while management accounting is not bound by relevant policies and regulations. Management accounting personnel can refer to the opinions of management accounting guidelines for implementation, which makes management accounting easier [4]. The strategic development of an enterprise requires related data to support it. The original financial and accounting information cannot fully meet the actual needs of the enterprise. This requires the use of related management accounting tools to reprocess the financial and accounting information to meet the strategic management and business decisions of the enterprise. Need.

Third, the management accounting talent gap is relatively large. In some western developed countries, the ratio of financial accounting to management accounting is 6:4, that is, 6 out of 10 financial personnel are financial accounting and 4 are management accounting. But most of the enterprises in China do not have management accounting positions, that is, $100 \%$ are financial accounting. Even though some large enterprises set up management accounting positions, management accounting positions are still less than $20 \%$, and more than $80 \%$ are still financial accounting. Some enterprises have realized the importance of management accounting. From internal management to decision-making, they need to use relevant management accounting tools to manage and process enterprise-related data and information to meet the needs of enterprises [5]. With the development of enterprise business, the proportion of financial accounting and management accounting will also undergo major changes in China. The proportion of financial accounting will gradually decrease, and the proportion of management accounting will increase.

Fourth, it can increase the employment channels of financial personnel. With the update of computer technology accounting methods, the application of big data, and the development of robotic accounting, no more financial personnel are needed for financial accounting positions. The original financial personnel must be transferred gradually from financial accounting to management accounting positions. At the same time, some of the added management accounting positions can also increase employment opportunities for newcomers. 


\section{The Necessity of the Transformation from Financial Accounting to Management Accounting in the Context of Big Data}

\subsection{Transformation is an inevitable trend under the development situation of information technology}

With the current rapid development of information technology, in the actual development of enterprise financial management, most of them are implemented using new scientific technologies [6]. On the basis of the use of big data information, the original manual accounting has been transformed into the use of information technology Processing data can not only ensure high efficiency and high performance, but also save financial and accounting human resources. Due to the impact of this large environment, the financial accounting function continues to shrink, requiring clear management ideas in financial work. This situation will inevitably lead to a transition to management accounting, and prompt financial personnel to continuously strengthen their logical thinking ability. In the actual development of the work, more powerful financial data can be provided to the senior management personnel to achieve better development of the enterprise.

\subsection{The transformation of the company's competitiveness is a strong support}

Compared with financial accounting, the application of more scientific data calculation methods in management accounting, and the use of flexible financial management methods, in the financial management activities, starting from the internal operation of the enterprise, coordinate local management and comprehensive development to obtain The long-term operation effect can provide strong data support in the process of enterprise management and enterprise decision-making and provide good management guarantee, which is very beneficial to the enterprise's production cost savings, management model optimization and capital utilization rate improvement, which can be beneficial to the market The implementation of scientific analysis and comprehensive control, on this basis, can effectively improve the market competitiveness of enterprises and achieve more ideal development of enterprises.

\subsection{The sustainable development of enterprises needs transformation}

With the continuous development of modern society, the economic situation in society is becoming more and more complex, and modern enterprises are gradually facing more and more competitive pressure in actual development, and enterprises can enhance their own competitive advantages in their actual development [7]. It is necessary to make use of relevant information resources in the context of big data. If the transformation of accounting methods cannot be realized in time, the ability to analyze the development and competitive advantages of enterprises in the course of accounting work can be improved, and enterprises cannot achieve sustainable development.

Comparing management accounting with financial accounting, management accounting can analyze the capital flow of an enterprise to provide detailed reports. It can achieve an advance budget for the future development of the enterprise and related investment plans, and can provide accurate financial information data to decision makers, so that the enterprise can achieve sustained and long-term development.

\section{Under the Background of Big Data, Effective Methods and Strategies for the Transformation of Financial Accounting to Management Accounting}

\subsection{Change of financial accounting management concept}

Some modern corporate managers are unaware of the important role of financial personnel in corporate management, and will not allow relevant financial personnel to participate in the management of the company. However, market development and lessons learned tell us that this backward management concept will seriously hinder corporate financial functions. The full play of 
the company has an important impact on the future development of the enterprise. Some university accounting students or accounting staff who have just entered the workplace believe that as long as they keep accurate accounts every day, file taxes on time, and summarize related reports, they are successful. Therefore, it is necessary to actively change the backward concept of these people in the enterprise. Only by enhancing financial management awareness can financial management personnel have the ability to collect, analyze, and process big data information, be aware of the opportunities and risks of the big data era, and improve the enterprise economy benefit.

\subsection{Transform the content of corporate financial work}

In the actual development of financial accounting in the past, it was often focused on accounting, using manual methods to calculate financial data in order to reasonably formulate financial statements. However, due to the professional quality of accounting staff, it is usually impossible to guarantee accounting [8]. The higher accuracy can accurately understand the financial situation of the enterprise, which results in a greater impact on the financial management effect of the enterprise.

On the basis of the current application of computer information technology, the previous laborious and cumbersome calculation situation can be changed, so that accounting staff have more time to mine the value of data information, which can make the accounting work richer and promote financial accounting. It can achieve a smooth transition to management accounting, more efficiently realize accounting information collection, analysis and processing, and make data information more complete and timely. By analyzing accounting information, accounting personnel can better understand the financial situation and actual operation of the enterprise, and can better identify the risks that exist in the enterprise's investment, so as to make a more reasonable choice of investment projects and promote the effective improvement of the company's economic benefits, So that the competitiveness of enterprises can be enhanced, so that enterprises can achieve more ideal development.

\subsection{Strengthen the comprehensive quality of accounting personnel}

At present, the composition structure of accounting personnel is still relatively complicated. Overall, the comprehensive qualities and abilities of accounting personnel have not been able to meet the requirements of the development of the times. As a result, the transition from financial accounting to management accounting will be subject to certain restrictions, which will affect the development of enterprises. It is necessary to strengthen the training of accountants to improve their overall quality. First of all, enterprises should strengthen the education and training of accounting staff, integrate management accounting knowledge in daily training, expand the horizon of accounting staff, and enable accounting staff to have modern management capabilities [9]. At the same time, accounting staff should be dispatched to go out to learn, to advanced enterprises to learn advanced management accounting knowledge. Secondly, to build a professional management accounting organization, in order to make this work better realized, it is necessary to strengthen the support of the government, so that the management accounting professional training has a better guarantee, so that it can get more ideal results Provide better talent support and guarantee for the transformation to management accounting.

\section{Conclusion}

The era of big data has had a huge impact on traditional enterprise financial accounting. The transformation of financial accounting to management accounting is an inevitable result of the development of enterprises and economy. Therefore, enterprises should fully understand the important role of financial accounting transformation, and take active measures to help them successfully transform into management accounting, in order to give full play to the value of accounting personnel in enterprise management, and ultimately create conditions for better development of enterprises under the background of big data 


\section{References}

[1] Susan M. Curtis. Formative assessment in accounting education and some initial evidence on its use for instructional sequencing. Journal of Accounting Education. 2011(4): 12.

[2] Gordon Boyce. Computer-assisted teaching and learning in accounting: pedagogy or product? Journal of Accounting Education. 1999(2): 34.

[3] Kala Saravanamuthu. Instilling a sustainability ethos in accounting education through the Transformative Learning pedagogy: A case-study. Critical Perspectives on Accounting. 2019(2): 24.

[4] Lars-Eric Bergevärn. Institutionalization of municipal accounting - a comparative study between Sweden and Norway. Scandinavian Journal of Management. 1995(1): 46.

[5] Jayne Bisman. MAKING ACCOUNTING HISTORIANS. The Accounting Historians Journal. 2019(1): 90.

[6] Samantha Sin, Alan Jones, Peter Petocz. Evaluating a method of integrating generic skills with accounting content based on a functional theory of meaning. Accounting \& Finance. 2017(1): 34.

[7] Nazli Hosal-Akman, Can Simga-Mugan. An assessment of the effects of teaching methods on academic performance of students in accounting courses. Innovations in Education and Teaching International. 2010(3): 56.

[8] Tracey Zhang, Lay-Chin Low, Poh-Sun Seow. Using online tutorials to teach the accounting cycle. Journal of Education for Business. 2019(4): 38.

[9] Oliveira Helena Costa, Rodrigues Lúcia Lima, Craig Russell. Bureaucracy and the balanced scorecard in health care settings. International journal of health care quality assurance, 2020, ahead-of-print (ahead-of-print). 